\title{
INTELLECTUAL INTELLIGENCE, LEARNING BEHAVIOR AND AVAILABILITY OF EDUCATIONAL MEANS ON INTERMEDIATE ACCOUNTING UNDERSTANDING WITH MOTIVATION AS A MODERATING VARIABLE
}

\begin{tabular}{|c|c|}
\hline \multicolumn{2}{|c|}{$\begin{array}{c}\text { Fitri Nuraini1 } \\
\text { a Universitas Muhammadiyah Surabaya, Indonesia } \\
\text { ftr_account@yahoo.co.id }\end{array}$} \\
\hline INFO ARTIKEL & ABSTRAK/ABSTRACT \\
\hline $\begin{array}{l}\text { Histori Artikel : } \\
\text { Tgl. Masuk : } 10 \text { Juli } 2019 \\
\text { Tgl. Diterima : } 29 \text { Agustus } 2019 \\
\text { Tersedia Online : } 30 \text { September } 2019 \\
\text { Keywords: } \\
\text { Intellectual Intelligence, Learning } \\
\text { Behavior, Availability Of Means Of } \\
\text { Education, Motivation, Understanding } \\
\text { Of Intermediate Financial Accounting. }\end{array}$ & $\begin{array}{l}\text { Intermediate Financial Accounting is a } \\
\text { continuation of accounting science from basic accounting, } \\
\text { the countain in intermediate financial accounting includes riil } \\
\text { account accounting treatment and special accounting } \\
\text { problems. Concepts in intermediate financial accounting } \\
\text { explain accounting treatment including recognition, } \\
\text { measurement, statement and disclosure. This study } \\
\text { examines the influence of intellectual intelligence, } \\
\text { accounting behavior and availability of educational facilities } \\
\text { on the understanding of intermediate financial accounting } \\
\text { with motivation as a moderating variable. } \\
\text { The sampling technique used convenience } \\
\text { sampling with a sampling of } 43 \text { students. The study uses } \\
\text { the Moderated Regression Analysis (MRA) analysis tool. } \\
\text { The results showed that (1) intellectual intelligence, } \\
\text { learning behavior and the availability of educational facilities } \\
\text { had no significant effect on the understanding of } \\
\text { intermediate financial accounting, (2) motivation to } \\
\text { moderate the influence of intellectual intelligence and } \\
\text { learning behavior on understanding middle financial } \\
\text { accounting, (3) motivation does not moderate the influence } \\
\text { of availability educational facilities for understanding middle } \\
\text { financial accounting. }\end{array}$ \\
\hline
\end{tabular}

\section{PENDAHULUAN}

Tingkat pemahaman mahasiswa secara umum tentang akuntansi merupakan hasil yang telah dicapai melalui usaha untuk menguasai, memahami ilmu akuntansi yang dinyatakan dengan nilai. Nilai ini merupakan nilai yang diperoleh oleh mahasiswa melalui latihan soal, studi kasus, kuis, Ujian Tengah Semester (UTS) dan Ujian Akhir Semester (UAS) selama satu semester. Dan seorang mahasiswa dalam memahami akuntansi tidak hanya ditunjang dengan nilai yang diperolehnya tetapi mahasiswa tersebut mengerti, memahami, menguasai konsep ilmu akuntansi baik secara teori maupun praktek. Definisi pemahaman merupakan kemampun diri dalam mengerti atau mengetahui dengan benar terhadap sesuatu (Anonim, www.asikbelajar.com, 2013). Tingkat pemahaman dipengaruhi oleh faktor ekternal dan internal, faktor internal diantaranya motivasi, dan kecerdasan. Untuk faktor eksternal dalam mempengaruhi tingkat pemahaman akuntansi diantaranya fasilitas sarana prasarana.

Kecerdasan intelektual $(I Q)$ lebih bersifat permanen, dan kecerdasan emosional $(E Q)$ justru memungkinkan 
untuk dipelajari kapanpun dan siapapun yang mempunyai keinginan untuk meraih sukses. Kecerdasan berkaitan dengan kemampuan kognitif yang dimiliki oleh masing-masing individu. Kecerdasan intelektual diukur dengan menggunakan alat psikometri atau sebagai tes IQ (Anonim,

(http://id.wikipedia.org/wiki/kecerdasan_in telektual).

Faktor internal lainnya yang mempengaruhi tingkat pemahaman adalah motivasi. Menurut Sardiman (2011:75) dalam penelitian Syahfitri (2014) motivasi belajar merupakan keseluruhan daya penggerak didalam diri mahasiswa yang menimbulkan kegiatan belajar,dan memberikan arah dalam kegiatan belajar sehingga tujuan yang dikehendaki dapat tercapai. Perilaku belajar juga merupakan faktor dalam mempengaruhi tingkat pemahaman,perilaku belajar dapat diartikan sebagai kebiasaan belajar yang erat kaitannya dengan penggunaan waktu yang baik untuk belajar maupun kegiatan lainnya. Menurut Hanifah dan Syukriy,2001 dalam Nugraha (2013) belajar yang efisien dapat dicapai apabila menggunakan strategi yang tepat dalam pengaturan waktu yang baik dalam kegiatan belajar maupun diluar belajar.

Untuk faktor eksternal yang mempengaruhi tingkat pemahaman adalah ketersediaan sarana prasarana lebih diutamakan sarana pendidikan. Fasilitas sarana prasarana ini salah satunya adalah ketersediaannya sarana pendidikan mencakup perabotan dan peralatan yang diperlukan sebagai kelengkapan setiap gedung/ruangan dalam menjalankan fungsinya untuk meningkatkan mutu dan relevansi hasil produk dan layanan (Slameto, 2010 dalam penelitian (Sitawati, 2017). Sarana pendidikan ini tentunya juga ditunjang dengan fasilitas referensi buku baik textbook dan non textbook yang terbaru, fasilitas internet (LAN dan WAN), sehingga wawasan dan ilmu pengetahuan yang diperoleh mahasiswa mengikuti perkembangan yang ada.

Kenyataannya, mayoritas

mahasiswa angkatan 2016 yang sudah menempuh akuntansi keuangan menengah masih belum memahami mengenai perlakuan akuntansi pada rekening riil dan masalah khusus akuntansi, hal ini kurangnya latihan soal dan studi kasus yang diperoleh oleh mahasiswa. Mahasiswa hanya belajar dikelas saja, dan referensi buku hanya dimiliki beberapa mahasiswa saja, hal ini disebabkan juga kurangnya kesadaran mahasiswa untuk berusaha memiliki buku akuntansi. Oleh karena itu diharapkan mahasiswa memiliki motivasi, perilaku belajar selain kecerdasan intelektual untuk memanfaatkan waktu dan fasilitas sarana pendidikan yang bertujuan untuk menggali ilmu mengenai akuntansi keuangan menengah dari sumber lain, misalnya browsing internet, membaca atau meminjam referensi buku diperpustakaan.

Pada penelitian ini akan menguji pengaruh kecerdasan intelektual, perilaku belajar dan ketersediaan sarana pendidikan terhadap pemahaman akuntansi keuangan menengah dengan motivasi sebagai variabel moderating. Peneliti dalam hal ini memilih motivasi sebagai variabel moderating yakni pemoderasi hubungan antara kecerdasan intelektual, perilaku belajar dan ketersediaan sarana pendidikan dengan pemahaman akuntansi keuangan menengah. Alasan peneliti memilih motivasi sebagai variabel moderating dikarenakan motivasi mulai terbentuk dari sikap kesadaran diri dalam pemahaman pentingnya belajar untuk memperoleh ilmu pengetahuan ((Anonim, http://www.AnneAhira.com, 2010). Menurut (Handoko, 2011), menjelaskan teori kebutuhan menurut Maslow dalam konsep motivasi belajar bahwa motivasi yang kuat akan semakin kuat juga dalam mempengaruhi perilaku seseorang untuk mempelajari dan memahami akuntansi keuangan menengah. Teori yang pertama tentang kebutuhan dasar, dihubungkan dengan fisik dan psikologis. Seseorang akan ada motivasi belajar yang kuat jika tidak diimbangi dengan makanan \& minuman serta psikologis yang bagus. Teori kedua tentang kebutuhan tumbuh, hal ini berkaitan dengan adanya kebutuhan 
untuk mengetahui dan memahami, keindahan dan aktualisasi diri.

Melalui 2 teori kebutuhan, maka dapat diketahui faktor - faktor kondisional apa saja yang berperan dalam memperkuat atau memperlemah hubungan antara kecerdasan intelektual, perilaku belajar dan ketersediaan sarana pendidikan terhadap pemahaman mahasiswa akuntansi semester 5 tentang akuntansi keuangan menengah. Dan dalam hal ini motivasi bisa merupakan salah satu faktor kondisional yang berperan dalam memperkuat atau memperlemah hubungan antara kecerdasan intelektual, perilaku belajar dan ketersediaan sarana pendidikan terhadap pemahaman mahasiswa akuntansi semester 5 tentang akuntansi keuangan menengah. Berdasarkan teori kebutuhan tersebut, penelitian ini mencoba untuk menguji hubungan tidak langsung antara kecerdasan intelektual, perilaku belajar dan ketersediaan sarana pendidikan dengan pemahaman mahasiswa akuntansi semester 5 tentang akuntansi keuangan menengah dengan memasukkan variabel motivasi sebagai variabel pemoderasi.

Objek dalam penelitian ini mahasiswa akuntansi angkatan 2016 yang masih aktif di Universitas Muhammadiyah Surabaya. Alasan obyek penelitian mahasiswa angkatan 2016 dikarenakan mahasiswa tersebut sudah menempuh matakuliah akuntansi keuangan menengah.

Sebelumnya penelitian yang pernah dilakukan terkait dengan kecerdasan intelektual, perilaku belajar dan ketersediaan sarana pendidikan serta pemahaman akuntansi adalah (Juliastantri, 2014), (Sitawati, 2017), (Filia, 2010), (Sahara, 2014), (Widyawati \& dkk, 2014), (Ernawati, 2017) dan Komalasari (2013) yang menunjukkan bahwa tingkat pemahaman materi akuntansi sebagai tolak ukur kemampuan calon akuntan dalam memahami, menguasai konsep dasar akuntansi baik dari pencatatan akuntansi sampai dengan pengungkapan laporan keuangan.
Dengan demikian penelitian ini berfokus pada pemahaman akuntansi keuangan menengah dan ditekankan pada pengaruh kecerdasan intelektual, perilaku belajar dan ketersediaan sarana pendidikan dengan motivasi sebagai moderating.

\section{KERANGKA TEORITIS DAN PENGEMBANGAN HIPOTESIS}

\section{Kecerdasan Intelektual}

Kecerdasan intelektual adalah kemampuan intelektual, analisa, logika dan rasio yang dimiliki oleh seorang mahasiswa. Pada penelitian ini akan menguji pengaruh kecerdasan intelektual terhadap pemahaman akuntansi keuangan menengah dengan motivasi sebagai variabel moderating. Menurut (Handoko, 2011), menjelaskan teori kebutuhan menurut Maslow dalam konsep motivasi belajar bahwa motivasi yang kuat akan semakin kuat juga dalam mempengaruhi perilaku seseorang untuk mempelajari dan memahami akuntansi keuangan menengah. Penelitian yang dilakukan oleh (Ernawati, 2017) menunjukkan kecerdasan emosional,kecerdasan intelektual, minat dan persepsi mahasiswa mengenai kompetensi dosen tidak berpengaruh pemahaman akuntansi. Akan tetapi penelitian Yorika dkk (2013) dan (Pasek, 2015) menunjukkan bahwa kecerdasan intelektual berpenagruh positif dan signifikan terhadap pemahaman akuntansi.

H1: Kecerdasan Intelektual Berpengaruh Secara Signifikan Terhadap Pemahaman Mahasiswa Mengenai Akuntansi Keuangan Menengah.

H1a : Motivasi Memoderasi Pengaruh Kecerdasan Intelektual Mahasiswa Terhadap Pemahaman Akuntansi Keuangan Menengah.

\section{Perilaku Belajar}

Perilaku belajar dapat diartikan
sebagai kebiasaan belajar, dan
merupakan dimensi belajar yang dilakukan
oleh individu secara berulang-ulang
sehingga menjadi otomatis (Filia, 2010).


Penelitian ini akan menguji pengaruh kecerdasan intelektual, perilaku belajar terhadap pemahaman akuntansi keuangan menengah dengan motivasi sebagai variabel moderating. Menurut (Handoko, 2011), menjelaskan teori kebutuhan menurut Maslow dalam konsep motivasi belajar bahwa motivasi yang kuat akan semakin kuat juga dalam mempengaruhi perilaku seseorang untuk mempelajari dan memahami akuntansi keuangan menengah. Teori yang pertama tentang kebutuhan dasar, dihubungkan dengan fisik dan psikologis. Penelitian yang dilakukan oleh (Widyawati \& dkk, 2014) menunjukkan perilaku belajar tidak berpengaruh terhadap tingkat pemahaman akuntansi, tetapi penelitian (Juliastantri, 2014) dan Komalasari (2013) menjelaskan bahwa perilaku belajar berpengaruh signifikan positif terhadap tingkat pemahaman pengantar akuntansi.

H2 : Perilaku Belajar Berpengaruh Secara Signifikan Terhadap Pemahaman Mahasiswa Mengenai Akuntansi Keuangan Menengah.

$\mathrm{H} 2 \mathrm{~b}$ : Motivasi Memoderasi Pengaruh Perilaku Belajar Mahasiswa Terhadap Pemahaman Akuntansi Keuangan Menengah.

\section{Ketersediaan Sarana Pendidikan}

Ketersediaan sarana pendidikan dalam penelitihan ini adalah sebagai variabel moderating. Sarana pendidikan yang digunakan adalah fasilitas berupa perangkat alat, bahan dan perabot yang secara langsung digunakan dalam proses pendidikan. Bentuk sarana pendidikan dimanfaatkan untuk memperoleh, menggali informasi mengenai pemahaman akuntansi keuangan menengah seperti jurnal, referensi buku, internet dan lainnya. Pada penelitian ini akan menguji pengaruh ketersediaan sarana pendidikan terhadap pemahaman akuntansi keuangan menengah dengan motivasi sebagai variabel moderating. Penelitian yang dilakukan oleh (Sitawati, 2017) menunjukkan sarana pendidikan tidak mempengaruhi secara langsung terhadap tingkat pemahaman akuntansi. Dan akan tetapi penelitian (Widaningrum \& dkk, 2010) menunjukkan minat memoderasi pengaruh sarana pendidikan terhadap tingkat pemahaman mahasiswa mengenai IFRS.

H3 : Ketersediaan Sarana Pendidikan Berpengaruh Secara Signifikan Terhadap Pemahaman Mahasiswa Mengenai Akuntansi Keuangan Menengah.

H3c : Motivasi Memoderasi Pengaruh Ketersediaan Sarana Pendidikan Mahasiswa Terhadap Pemahaman Akuntansi Keuangan Menengah.

\section{METODOLOGI PENELITIAN}

Objek penelitian ini adalah Universitas Muhammadiyah Surabaya, populasinya adalah mahasiswa Fakultas Ekonomi dan Bisnis program studi akuntansi angkatan 2016 kelas regular pagi sebanyak 25 mahasiswa dan kelas regular sore sebanyak 27 mahasiswa. Dengan jumlah sampel keseluruhan sebanyak 52 mahasiswa

Sampel ditentukan dengan teknik convenience sampling yang bersifat nonprobabilistik. Ukuran sampel yang dibutuhkan dalam penelitian ini diperoleh dari rumus Slovin (Umar, 2004) dengan formula sebagai berikut :

$$
\mathrm{n} \quad=\frac{\mathrm{N}}{1+\mathrm{Ne}^{2}}
$$

Dimana :

$$
\begin{array}{ll}
\mathrm{n} & =\text { Ukuran sampel } \\
\mathrm{N} & =\text { Ukuran populasi } \\
\mathrm{e} & =\text { Persen } \\
& \text { ketidaktelitian karena kesalahan } \\
& \text { pengambilan sampel yang masih } \\
& \text { dapat ditolerir atau diinginkan. }
\end{array}
$$

Maka :

$\mathrm{n}=\frac{52}{1+(52)(0.1)^{2}}=34.211$

Dibulatkan menjadi 34 responden, sehingga dalam penelitian ini jumlah sampel yang dibutuhkan paling sedikit 34 responden.

Jenis penelitian ini adalah penelitian kuantitatif menggunakan data primer dan sekunder ,untuk data primer dengan teknik pengumpulan data melalui kuesioner yaitu dengan cara memberikan kuesioner kepada 52 mahasiswa prodi akuntansi angkatan 2016 yang masih aktif dalam perkuliahan di Universitas 
Muhammadiyah Surabaya. Dan data sekunder diperoleh dari bagian Dikjar Fakultas Ekonomi dan Bisnis Universitas Muhammadiyah Surabaya dan keterangan lain yang berkaitan dengan data yang dibutuhkan.

\section{Pengukuran Variabel}

\section{a. Kecerdasan Intelektual $\left(\mathbf{X}_{1}\right)$}

Kecerdasan intelektual adalah kemampuan intelektual, analisa, logika dan rasio yang dimiliki oleh seorang mahasiswa. Variabel kecerdasan intelektual diukur dengan menggunakan indikator yang dikembangkan oleh Dwijayanti (2009) dan diuji dengan 3 (tiga) pernyataan mengenai kemampuan memecahkan masalah, intelegensi verbal, dan intelegensi praktis.

\section{b. Perilaku Belajar $\left(\mathbf{X}_{2}\right)$}

Perilaku belajar dapat diartikan sebagai kebiasaan belajar, dan merupakan dimensi belajar yang dilakukan oleh individu secara berulang-ulang sehingga menjadi otomatis (Filia, 2010). Variabel ini diukur dengan indikator menggunakan kuesioner yang diadopsi dari Nugraha (2013), dalam hal peneliti merubah beberapa item kuesioner dan diuji dengan 4 butir pernyataan mengenai kebiasaan mengikuti pelajaran : kebiasaan membaca buku; (3) kunjungan ke perpustakaan; dan (4) kebiasaan menghadapi ujian.

c. Ketersediaan Sarana Pendidikan $\left(X_{3}\right)$

Ketersediaan sarana pendidikan dalam penelitihan ini adalah sebagai variabel moderating. Sarana pendidikan yang digunakan adalah fasilitas berupa perangkat alat, bahan dan perabot yang secara langsung digunakan dalam proses pendidikan. Bentuk sarana pendidikan dimanfaatkan untuk memperoleh, menggali informasi mengenai pemahaman akuntansi keuangan menengah seperti jurnal, referensi buku, internet dan lainnya. Variabel ini diukur dengan indikator

menggunakan acuan kuesioner dibuat oleh Rijatno (2008) yang dikembangkan oleh peneliti dengan item pernyataan berkaitan dengan tersedianya fasilitas sarana prasarana pendidikan.

\section{d. Motivasi $\left(\mathbf{X}_{\mathbf{4}}\right)$}

Motivasi yang digunakan adalah motivasi terhadap pengetahuan mengenai akuntansi keuangan menengah. Motivasi terhadap akuntansi menengah ini diukur dari seberapa besar keinginan individu dalam mempelajari dan mencari informasi mengenai akuntansi menengah. Variabel ini diukur dengan indikator menurut teori Maslow dan diuji dengan 2 (2) butir pernyataan mengenai (1) kebutuhan dasar meliputi kebutuhan fisiologis; kebutuhan akan rasa aman; kebutuhan untuk dicintai; kebutuhan untuk dihargai ; dan (2) kebutuhan tumbuh, yang terdiri dari: kebutuhan untuk mengetahui dan memahami; kebutuhan keindahan; kebutuhan aktualisasi diri.

\section{e. Pemahaman Akuntansi Keuangan Menengah (Y)}

Kemampuan mahasiswa dalam memahami dan mengerti mengenai akuntansi keuangan menengah dan dinyatakan dalam bentuk rata-rata nilai Akuntansi Keuangan Menengah 1 dan 2. Pengukuran skala likert adalah point 1 menunjukkan nilai $\mathrm{E}$, point 2 menunjukkan nilai $\mathrm{D}$, point 3 menunjukkan nilai $\mathrm{C}$, point 4 menunjukkan nilai $B$, dan point 5 menunjukkan nilai A. Alat ukur yang digunakan untuk mengukur variabel tingkat pemahaman akuntansi keuangan menengah adalah dengan menggunakan kuesioner yang diadopsi oleh Nugraha (2013). Satuan pengukuran yang digunakan untuk variabel bebas dan terikat adalah skala likert. Berikut bobot nilai jawaban kuisioner sebagai berikut :

$\begin{array}{ll}\text { Sangat Setuju } & 5 \\ \text { Setuju } & 4 \\ \text { Ragu - ragu } & 3 \\ \text { Tidak Setuju } & 2 \\ \text { Sangat Tidak Setuju } & 1 \\ \text { Sumber : (Sugiyono, 2012) } & \end{array}$

\section{Teknik Pengujian Hipotesis Uji Validitas}

Sebuah instrumen memiliki validitas tinggi jika butir-butir yang membentuk instrumen tidak menyimpang dari fungsi instrumen tersebut. Menurut (Ghozali, 2013) syarat minimum agar suatu butir dapat dianggap valid jika diperoleh nilai $r$ hitung $>r$ table. 


\section{Uji Reliabilitas}

Uji reliabilitas ini menggunakan reliabilitas konsistensi internal yaitu teknik cronbach Alpha (a). Apabila nilai cronbach Alpha dari hasil pengujian $>0.70$ maka dapat dikatakan bahwa konstruk atau variabel itu adalah reliable (Ghozali, 2013).

\section{Uji Normalitas}

Uji normalitas digunakan untuk mengetahui apakah suatu data mengikuti sebaran normal atau tidak dengan menggunakan metode Kolmogrov Smirnov dan metode Shapiro Wilk. Menurut (Sumarsono, 2007) pedoman dalam mengambil keputusan, apakah sebuah distribusi data mengikuti distribusi normal jika nilai signifikan atau nilai probabilitas $>0,05$.

\section{Teknik Analisis dan Uji Hipotesis}

Pengujian terhadap hipotesis dilakukan dengan menggunakan uji statistik $f$ dan $t$, yaitu pengujian koefisien untuk mengetahui pengaruh baik secara simultan maupun parsial dari setiap variabel independen terhadap variabel dependennya. Dan untuk menguji pengaruh variabel moderasi digunakan MRA (Moderated Regression Analysis) dengan rumus persamaan regresi :

$$
\begin{aligned}
Y \quad= & a+b_{1} X_{1}+b_{2} X_{2}+b_{3} X_{3}+b_{4} X_{4} \\
& +b_{5}\left|X_{1}-X_{4}\right|+e \ldots(1) \\
Y \quad= & a+b_{1} X_{1}+b_{2} X_{2}+b_{3} X_{3}+b_{4} X_{4} \\
& +b_{5}\left|X_{2}-X_{4}\right|+e \ldots(2) \\
= & a+b_{1} X_{1}+b_{2} X_{2}+b_{3} X_{3}+b_{4} X_{4} \\
& +b_{5}\left|X_{3}-X_{4}\right|+e \ldots(3)
\end{aligned}
$$

\section{HASIL DAN PEMBAHASAN}

Kuisioner yang disebarkan sebanyak 52 kuisioner dari mahasiswa prodi akuntansi angkatan 2016 aktif diUniversitas Muhammadiyah Surabaya. Penyebaran kuesioner dilakukan pada waktu pelaksanaan proses belajar mengajar. Dan setelah dilakukan pengeditan data dan persiapan untuk pengolahan, 9 kuisioner diputuskan tidak digunakan dalam analisa karena pengisian kuisioner kurang lengkap. Gambaran selengkapnya mengenai proses penyebaran dan penerimaan kuisioner dapat dilihat pada tabel berikut :
Tabel 1. Gambaran Proses Penyebaran dan Penerimaan Kuisioner

\begin{tabular}{lcc}
\hline \multicolumn{2}{c}{ Keterangan } & $\begin{array}{c}\text { Jumlah } \\
\text { Kuisioner }\end{array}$ \\
\hline $\begin{array}{l}\text { Kuisioner } \\
\text { disebar }\end{array} \quad$ yang & 52 \\
$\begin{array}{l}\text { Kuisioner } \\
\text { diterima }\end{array}$ & yang & 43 \\
$\begin{array}{l}\text { Kuisioner yang tidak } \\
\text { digunakan/diolah }\end{array}$ & 9 \\
$\begin{array}{l}\text { Prosentase } \\
\text { Kuisioner yang valid }\end{array}$ & $100 \%$ \\
\hline \multicolumn{1}{c}{ Prosentase } & 83 \\
\hline
\end{tabular}

Berdasarkan data yang diperoleh dari 43 responden, berikut ini dipaparkan mengenai jumlah responden berdasarkan kelas reguler. Berikut ini deskripsi gambaran responden yaitu mahasiswa prodi akuntansi semester 5 Universitas Muhammadiyah Surabaya yang aktif dalam perkuliahan.

Tabel 2. Berdasarkan Kelas Reguler

\begin{tabular}{|l|l|l|l|}
\hline No. & $\begin{array}{l}\text { Kelas } \\
\text { Reguler }\end{array}$ & Jumlah & $\begin{array}{l}\text { Prosentase } \\
(\%)\end{array}$ \\
\hline 1. & Pagi & 21 & 49 \\
\hline 2. & Sore & 22 & 51 \\
\hline \multicolumn{2}{|l}{ Jumlah } & 43 & 100 \\
\hline
\end{tabular}

Pada tabel 2 menunjukkan bahwa responden berasal dari mahasiswa prodi akuntansi semester 5 kelas regular sore Universitas Muhammadiyah Surabaya yaitu $51 \%$. Hal ini dikarenakan mahasiswa kelas regular sore mengalami kenaikan dari Tahun Akademik sebelumnya.

\section{Uji Analisis Data Uji Validitas}

Hasil uji validitas untuk variabel kecerdasan intelektual (X1), perilaku belajar (X2), ketersediaan sarana pendidikan (X3) dan motivasi (X4) dan pemahaman akuntansi keuangan menengah $(Y)$ dapat dilihat dari tabel-tabel dibawah ini :

1. Hasil Uji Validitas Kecerdasan Intelektual (X1)

Tabel 3. Hasil Uji Validitas Variabel Kecerdasan Intelektual $\left(\mathrm{X}_{1}\right)$

\begin{tabular}{|l|l|l|l|}
\hline Pernyataan & $\begin{array}{c}\text { Koefisien } \\
\text { korelasi } \\
(r)\end{array}$ & $\begin{array}{c}\text { Nilai } \\
r \\
\text { tabel }\end{array}$ & Penilaian \\
\hline $\mathrm{X} 1-1$ & 0.780 & 0.301 & Valid \\
\hline $\mathrm{X} 1-2$ & 0.664 & 0.301 & Valid \\
\hline $\mathrm{X} 1-3$ & 0.724 & 0.301 & Valid \\
\hline $\mathrm{X} 1-4$ & 0.811 & 0.301 & Valid \\
\hline
\end{tabular}




\begin{tabular}{|l|l|l|l|}
\hline Pernyataan & $\begin{array}{c}\text { Koefisien } \\
\text { korelasi } \\
(r)\end{array}$ & $\begin{array}{c}\text { Nilai } \\
r \\
\text { tabel }\end{array}$ & Penilaian \\
\hline $\mathrm{X} 1-5$ & 0.842 & 0.301 & Valid \\
\hline $\mathrm{X} 1-6$ & 0.688 & 0.301 & Valid \\
\hline $\mathrm{X} 1-7$ & 0.668 & 0.301 & Valid \\
\hline $\mathrm{X} 1-8$ & 0.862 & 0.301 & Valid \\
\hline $\mathrm{X} 1-9$ & 0.873 & 0.301 & Valid \\
\hline $\mathrm{X} 1-10$ & 0.834 & 0.301 & Valid \\
\hline
\end{tabular}

Sumber : Data Diolah (2019)

Berdasarkan hasil uji validitas terhadap 10 pernyataan yang terdapat di dalam kuisioner yang disebarkan kepada mahasiswa prodi akuntansi semester 5

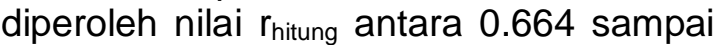
dengan 0.873 yang lebih besar dari nilai $r_{\text {tabel }}$ sebesar 0.301 sehingga 10 pernyataan dianggap valid.

\section{Hasil Uji Validitas Perilaku Belajar} (X2)

Tabel 4. Hasil Uji Validitas Variabel Perilaku Belajar $\left(X_{2}\right)$

\begin{tabular}{|l|l|l|l|}
\hline Pernyataan & $\begin{array}{c}\text { Koefisien } \\
\text { korelasi } \\
(r)\end{array}$ & $\begin{array}{c}\text { Nilai } r \\
\text { tabel }\end{array}$ & Penilaian \\
\hline X2-1 & 0.660 & 0.301 & Valid \\
\hline X2-2 & 0.634 & 0.301 & Valid \\
\hline X2-3 & 0.764 & 0.301 & Valid \\
\hline X2-4 & 0.736 & 0.301 & Valid \\
\hline X2-5 & 0.715 & 0.301 & Valid \\
\hline X2-6 & 0.577 & 0.301 & Valid \\
\hline X2-7 & 0.694 & 0.301 & Valid \\
\hline X2-8 & 0.546 & 0.301 & Valid \\
\hline X2-9 & 0.414 & 0.301 & Valid \\
\hline$X 2-10$ & 0.784 & 0.301 & Valid \\
\hline
\end{tabular}

Sumber : Data Diolah (2019)

Berdasarkan hasil uji validitas terhadap 10 pernyataan yang terdapat di dalam kuisioner yang disebarkan kepada mahasiswa prodi akuntansi semester 5 diperoleh nilai $\mathrm{r}_{\text {hitung }}$ antara 0.414 sampai dengan 0.784 yang lebih besar dari nilai $r_{\text {tabel }}$ sebesar 0.301 sehingga 10 pernyataan dianggap valid.

3. Hasil Uji Validitas Ketersediaan Sarana Pendidikan (X3)

Tabel 5. Hasil Uji Validitas Variabel Ketersediaan Sarana Pendidikan $\left(\mathrm{X}_{3}\right)$

\begin{tabular}{|l|l|l|l|}
\hline Pernyataan & $\begin{array}{l}\text { Koefisien } \\
\text { korelasi } \\
(\mathrm{r})\end{array}$ & $\begin{array}{l}\text { Nilai } r \\
\text { tabel }\end{array}$ & Penilaian \\
\hline X3-1 & 0.580 & 0.301 & Valid \\
\hline X3-2 & 0.564 & 0.301 & Valid \\
\hline X3-3 & 0.760 & 0.301 & Valid \\
\hline
\end{tabular}

\begin{tabular}{|l|l|l|l|}
\hline Pernyataan & $\begin{array}{l}\text { Koefisien } \\
\text { korelasi } \\
(r)\end{array}$ & $\begin{array}{l}\text { Nilai } r \\
\text { tabel }\end{array}$ & Penilaian \\
\hline X3-4 & 0.824 & 0.301 & Valid \\
\hline X3-5 & 0.788 & 0.301 & Valid \\
\hline X3-6 & 0.777 & 0.301 & Valid \\
\hline X3-7 & 0.806 & 0.301 & Valid \\
\hline
\end{tabular}

Sumber : Data Diolah (2019)

Berdasarkan hasil uji validitas terhadap 7 pernyataan yang terdapat di dalam kuisioner yang disebarkan kepada mahasiswa prodi akuntansi semester 5

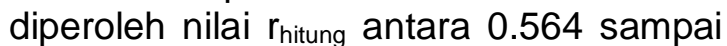
dengan 0.824 yang lebih besar dari nilai $r_{\text {tabel }}$ sebesar 0.301 sehingga 7 pernyataan dianggap valid.

4. Hasil Uji Validitas Motivasi (X4) Tabel 6. Hasil Uji Validitas 1 Variabel Motivasi $\left(\mathbf{X}_{4}\right)$

\begin{tabular}{|l|l|l|l|}
\hline Pernyataan & $\begin{array}{l}\text { Koefisien } \\
\text { korelasi } \\
(r)\end{array}$ & $\begin{array}{l}\text { Nilai } r \\
\text { tabel }\end{array}$ & Penilaian \\
\hline$X 4-1$ & 0.812 & 0.301 & Valid \\
\hline$X 4-2$ & 0.331 & 0.301 & Valid \\
\hline$X 4-3$ & 0.810 & 0.301 & Valid \\
\hline$X 4-4$ & 0.831 & 0.301 & Valid \\
\hline$X 4-5$ & 0.854 & 0.301 & Valid \\
\hline$X 4-6$ & 0.766 & 0.301 & Valid \\
\hline$X 4-7$ & 0.772 & 0.301 & Valid \\
\hline$X 4-8$ & 0.824 & 0.301 & Valid \\
\hline$X 4-9$ & 0.786 & 0.301 & Valid \\
\hline$X 4-10$ & 0.850 & 0.301 & Valid \\
\hline$X 4-11$ & 0.781 & 0.301 & Valid \\
\hline$X 4-12$ & 0.126 & 0.301 & $\begin{array}{l}\text { Tidak } \\
\text { Valid }\end{array}$ \\
\hline
\end{tabular}

Sumber : Data Diolah (2019)

Berdasarkan hasil uji validitas terhadap 12 pernyataan yang terdapat di dalam kuisioner yang disebarkan kepada mahasiswa prodi akuntansi semester 5 diperoleh nilai $r_{\text {hitung }}$ sebesar 0.126 lebih kecil dari nilai $r_{\text {tabel }}$ sebesar 0.301 sehingga hanya 11 pernyataan dianggap valid sisanya tidak valid. Dan dilakukan uji validitas kedua sehingga data yang disajikan memenuhi kriteria valid yaitu > 0.301 .

Tabel 7. Hasil Uji Validitas 2 Variabel Motivasi $\left(\mathbf{X}_{4}\right)$

\begin{tabular}{|l|l|l|l|}
\hline Pernyataan & $\begin{array}{l}\text { Koefisien } \\
\text { korelasi } \\
(r)\end{array}$ & $\begin{array}{l}\text { Nilai } r \\
\text { tabel }\end{array}$ & Penilaian \\
\hline $\mathrm{X} 4-1$ & 0.831 & 0.301 & Valid \\
\hline
\end{tabular}




\begin{tabular}{|l|l|l|l|}
\hline Pernyataan & $\begin{array}{l}\text { Koefisien } \\
\text { korelasi } \\
(r)\end{array}$ & $\begin{array}{l}\text { Nilai } r \\
\text { tabel }\end{array}$ & Penilaian \\
\hline$X 4-2$ & 0.461 & 0.301 & Valid \\
\hline$X 4-3$ & 0.798 & 0.301 & Valid \\
\hline$X 4-4$ & 0.794 & 0.301 & Valid \\
\hline$X 4-5$ & 0.864 & 0.301 & Valid \\
\hline$X 4-6$ & 0.776 & 0.301 & Valid \\
\hline$X 4-7$ & 0.776 & 0.301 & Valid \\
\hline$X 4-8$ & 0.818 & 0.301 & Valid \\
\hline$X 4-9$ & 0.759 & 0.301 & Valid \\
\hline$X 4-10$ & 0.808 & 0.301 & Valid \\
\hline$X 4-11$ & 0.769 & 0.301 & Valid \\
\hline
\end{tabular}

Sumber : Data Diolah (2019)

5. Hasil Uji Validitas Pemahaman Akuntansi Keuangan Menengah (Y)

Tabel 8. Hasil Uji Validitas Variabel

Pemahaman Akuntansi Dasar (Y)

\begin{tabular}{|l|l|l|l|}
\hline Pernyataan & $\begin{array}{l}\text { Koefisien } \\
\text { korelasi } \\
(\mathrm{r})\end{array}$ & $\begin{array}{l}\text { Nilai } \mathrm{r} \\
\text { tabel }\end{array}$ & Penilaian \\
\hline Y-1 & 0.580 & 0.301 & Valid \\
\hline Y -2 & 0.564 & 0.301 & Valid \\
\hline Y -3 & 0.760 & 0.301 & Valid \\
\hline Y - 4 & 0.824 & 0.301 & Valid \\
\hline Y -5 & 0.788 & 0.301 & Valid \\
\hline Y -6 & 0.777 & 0.301 & Valid \\
\hline Y -7 & 0.806 & 0.301 & Valid \\
\hline
\end{tabular}

Sumber : Data Diolah (2019)

Berdasarkan hasil uji validitas terhadap 7 pernyataan yang terdapat di dalam kuisioner yang disebarkan kepada mahasiswa prodi akuntansi semester 5 diperoleh nilai $r_{\text {hitung }}$ antara 0.564 sampai dengan 0.824 yang lebih besar dari nilai $r_{\text {tabel }}$ sebesar 0.301 sehingga 7 pernyataan dianggap valid.

\section{Uji Reliabilitas}

Hasil uji reliabilitas pada variabel bebas dan terikat dapat dilihat pada tabel di bawah ini :

Tabel 9. Uji Reliabilitas

\begin{tabular}{|l|l|l|}
\hline Variabel & R Alpha & Hasil \\
\hline $\begin{array}{l}\text { Pemahaman } \\
\text { Akuntansi } \\
\text { Keuangan } \\
\text { Menengah }(\mathrm{Y})\end{array}$ & 0.853 & Reliabel \\
\hline $\begin{array}{l}\text { Kecerdasan } \\
\text { Intelektua }\left(\mathrm{X}_{1}\right)\end{array}$ & 0.923 & Reliabel \\
\hline Perilaku Belajar $\left(\mathrm{X}_{2}\right)$ & 0.842 & Reliabel \\
\hline
\end{tabular}

\begin{tabular}{|l|l|l|}
\hline Variabel & R Alpha & Hasil \\
\hline $\begin{array}{l}\text { Ketersediaan } \\
\text { Sarana Pendidikan } \\
\left(X_{3}\right)\end{array}$ & 0.853 & Reliabel \\
\hline Motivasi $\left(X_{4}\right)$ & 0.909 & Reliabel \\
\hline
\end{tabular}

Sumber : Data Diolah (2019)

Hasil uji reliabilitas dari variabel bebas dan terikat diatas menunjukan nilai yang lebih dari 0,70 sehingga dapat disimpulkan bahwa seluruh variabel dalam penelitian ini adalah reliabel.

\section{Uji Normalitas}

Hasil uji normalitas untuk variabel Kecerdasan Intelektual (X1), Perilaku Belajar (X2), Ketersediaan Sarana Pendidikan (X3), Motivasi (X4), dan Pemahaman Akuntansi Keuangan Menengah (Y) dapat dilihat pada tabel uji statistik non parametrik KolmogorovSmirnov (K-S) di bawah ini :

Tabel 10 Uji Normalitas

One-Sample Kolmogorov-Smirnov Test

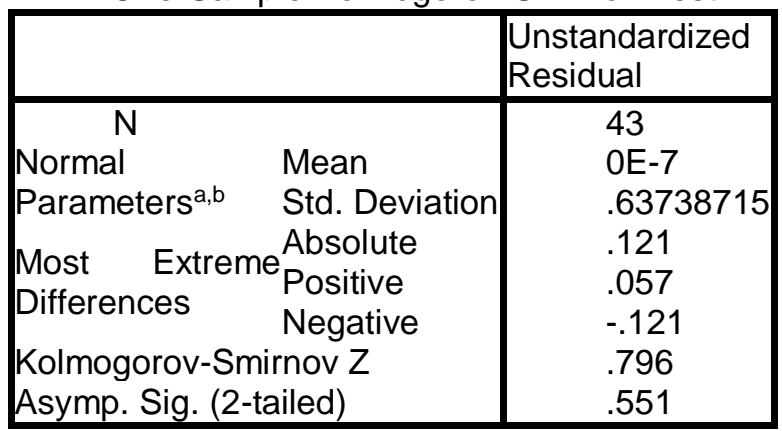

a. Test distribution is Normal.

b. Calculated from data.

Sumber : Data Diolah (2019)

Berdasarkan hasil uji normalitas menggunakan uji statistik non parametrik Kolmogorov-Smirnov (K-S hasil ujinya menunjukkan variabel $X$ dan $Y$ yang berdistribusi normal, karena tingkat signifikan yang dihasilkan diatas $5 \%$, yaitu 0.551

\section{Analisis Pengujian Asumsi Klasik - Pengujian Multikolinier}

Identifikasi ada atau tidaknya gejala multikolinier dilakukan dengan menghitung Variance Inflation Factor (VIF). Nilai VIF untuk masing-masing variabel diatas bahwa nilai VIF seluruh variabel bebas dan variabel moderating lebih kecil dari 10, artinya kedua variabel 
bebas dan satu variabel moderating pada penelitian ini tidak ada gejala multikolinier.

\section{- Pengujian Heterokedastisitas}

Uji heteroskedastisitas bertujuan menguji apakah dalam model regresi terjadi ketidaksamaan variance dari residual satu pengamatan ke pengamatan yang lain. Hal tersebut dapat dilihat pada hasil pengujian output nonparametric correlations diketahui bahwa masingmasing variabel bebas dan variabel moderating berada diatas signifikan $5 \%$. Ini berarti variabel bebas dan variabel moderating pada penelitian ini tidak ada gejala heteroskedastisitas.

\section{- Persamaan Analisis Regresi Moderating \\ Persamaan analisis regresi} moderating dengan model nilai selisih mutlak sebagai berikut :

$Y=3.516-0.261 X_{1}+0.112 X_{2}+0.003 X_{3}+$ $0.348 \mathrm{X}_{4}+0.549\left(\mathrm{X}_{1}-\mathrm{X}_{4}\right) \ldots(1)$

$Y=3.462-0.338 X_{1}+0.042 X_{2}+0.004 X_{3}+$ $0.418 X_{4}+0.425\left(X_{2}-X_{4}\right) \ldots(2)$

$Y=3.529-0.395 X_{1}+0.143 X_{2}+0.033 X_{3}+$ $0.367 X_{4}+0.312\left(X_{3}-X_{4}\right) \ldots(3)$

\section{Pengujian Hipotesis}

Hasil uji hipotesis pada penelitian ini terdapat dua analisis dan dua uji hipotesis adalah sebagai berikut :

\section{Pengaruh Kecerdasan Intelektual Terhadap Pemahaman Akuntansi Keuangan Menengah Dengan Motivasi sebagai Variabel Moderating.}

Tabel 11. Hasi uji F (ANOVA)

\begin{tabular}{|c|c|c|c|c|c|}
\hline $\begin{array}{l}\text { Sumb } \\
\text { er } \\
\text { varian }\end{array}$ & $\begin{array}{c}\text { Jumla } \\
\text { h } \\
\text { kuadra } \\
\mathbf{t}\end{array}$ & $\begin{array}{l}\mathrm{D} \\
\mathrm{f}\end{array}$ & $\begin{array}{l}\text { Kuadr } \\
\text { at } \\
\text { tengah }\end{array}$ & F hit & Sig. \\
\hline $\begin{array}{l}\text { Regres } \\
\text { i }\end{array}$ & 4.053 & 5 & 0.811 & 1.758 & \begin{tabular}{|l|}
0.14 \\
6
\end{tabular} \\
\hline Sisa & 17.063 & $\begin{array}{l}3 \\
7\end{array}$ & 0.461 & & \\
\hline Total & 21.116 & $\begin{array}{l}4 \\
2\end{array}$ & & & \\
\hline
\end{tabular}

Sumber : Data Diolah (2019)

Berdasarkan tabel diatas dapat diketahui nilai $F$ hitung yang diperoleh dari pengolahan data adalah 1.758 dengan tingkat siginifikansi sebesar 0,146 atau lebih besar 0.05 maka Ho diterima dengan Ha ditolak, yang artinya model yang digunakan adalah untuk mengetahui berpengaruh tidak siginifikan kecerdasan intelektual $\left(X_{1}\right)$, perilaku belajar $\left(X_{2}\right)$, ketersediaan sarana pendidikan $\left(X_{3}\right)$ dan motivasi $\left(X_{4}\right)$ terhadap pemahaman akuntansi keuangan menengah $(Y)$.

Uji $t$ dapat digunakan untuk mengetahui signifikan atau tidaknya pengaruh secara parsial kecerdasan intelektual $\left(X_{1}\right)$, perilaku belajar $\left(X_{2}\right)$, ketersediaan sarana pendidikan $\left(X_{3}\right)$ dan motivasi $\left(\mathrm{X}_{4}\right)$ terhadap pemahaman akuntansi keuangan menengah $(\mathrm{Y})$.

Tabel 12. Hasil uji t

\begin{tabular}{|c|c|c|c|c|}
\hline Variabel & $\begin{array}{c}\text { t } \\
\text { hitu } \\
\text { ng }\end{array}$ & Sig. & $\begin{array}{c}\text { Kriteria } \\
\text { Penguji } \\
\text { an }\end{array}$ & $\begin{array}{c}\text { Kesimpul } \\
\text { an }\end{array}$ \\
\hline $\begin{array}{l}\text { Kecerdas } \\
\text { an } \\
\text { Intelektua } \\
\mathrm{I}\left(\mathrm{X}_{1}\right)\end{array}$ & $\begin{array}{l}- \\
1.38 \\
1\end{array}$ & $\begin{array}{l}0.17 \\
6\end{array}$ & \multirow{5}{*}{$\begin{array}{l}\text { Jika nilai } \\
\text { probabili } \\
\text { tas (P } \\
\text { value)/si } \\
\text { gnifikan } \\
>\quad 0.05 \\
\text { maka } \\
\text { Ho } \\
\text { diterima } \\
\text { dan Ha } \\
\text { ditolak } \\
\text { Jika nilai } \\
\text { probabili } \\
\text { tas (P } \\
\text { value)/si } \\
\text { gnifikan } \\
<\quad 0.05 \\
\text { maka } \\
\text { Ho } \\
\text { ditolak } \\
\text { dan Ha } \\
\text { diterima }\end{array}$} & $\begin{array}{l}\text { Ho } \\
\text { diterima } \\
\text { dan Ha } \\
\text { ditolak }\end{array}$ \\
\hline $\begin{array}{l}\text { Perilaku } \\
\text { Belajar } \\
\left(\mathrm{X}_{2}\right)\end{array}$ & $\begin{array}{l}0.79 \\
8\end{array}$ & $\begin{array}{l}0.43 \\
0\end{array}$ & & $\begin{array}{l}\text { Ho } \\
\text { diterima } \\
\text { dan Ha } \\
\text { ditolak }\end{array}$ \\
\hline $\begin{array}{l}\text { Ketersedi } \\
\text { aan } \\
\text { Sarana } \\
\text { Pendidika } \\
\mathrm{n}\left(\mathrm{X}_{3}\right)\end{array}$ & $\begin{array}{l}0.02 \\
4\end{array}$ & $\begin{array}{l}0.98 \\
1\end{array}$ & & $\begin{array}{l}\text { Ho } \\
\text { diterima } \\
\text { dan Ha } \\
\text { ditolak }\end{array}$ \\
\hline $\begin{array}{l}\text { Motivasi } \\
\left(\mathrm{X}_{4}\right)\end{array}$ & $\begin{array}{l}1.96 \\
6\end{array}$ & $\begin{array}{l}0.05 \\
7\end{array}$ & & $\begin{array}{l}\text { Ho } \\
\text { diterima } \\
\text { dan Ha } \\
\text { ditolak }\end{array}$ \\
\hline $\begin{array}{l}\text { Interaksi } \\
\text { antara } \\
\text { variabel } \\
\text { Kecerdas } \\
\text { an } \\
\text { Intelektua } \\
\text { I dan } \\
\text { Motivasi } \\
\left(X_{1} X_{4}\right)\end{array}$ & $\begin{array}{l}2.09 \\
6\end{array}$ & $\begin{array}{l}0.04 \\
3\end{array}$ & & $\begin{array}{l}\text { Ho ditolak } \\
\text { dan Ha } \\
\text { diterima }\end{array}$ \\
\hline
\end{tabular}

Sumber : Data Diolah (2019)

Hasil uji t menunjukkan bahwa variabel kecerdasan intelektual $\left(\mathrm{X}_{1}\right)$, berpengaruh tidak signifikan terhadap pemahaman mahasiswa prodi akuntansi semester 5 Universitas Muhammadiyah Surabaya mengenai akuntansi keuangan menengah. Hal ini ditunjukkan dari nilai $t$ hitung sebesar -1.381 dengan signifikansi 0.176 yang lebih besar dari 0.05 . Hasil uji t berikutnya menunjukkan bahwa terdapat pengaruh tidak signifikan perilaku belajar 
$\left(\mathrm{X}_{2}\right)$ terhadap pemahaman akuntansi keuangan menengah. Hal tersebut ditunjukkan dari nilai $t$ hitung sebesar 0.798 dengan signifikansi 0.430 yang lebih besar dari 0.05 .

Hasil uji t juga menunjukkan bahwa variabel ketersediaan sarana pendidikan $\left(X_{3}\right)$, berpengaruh tidak signifikan terhadap pemahaman mahasiswa prodi akuntansi semester 5 Universitas Muhammadiyah Surabaya mengenai akuntansi keuangan menengah. Hal ini ditunjukkan dari nilai $t$ hitung sebesar 0.024 dengan signifikansi 0.981 yang lebih besar dari 0.05. Untuk hasil uji t menunjukan pula bahwa motivasi memoderasi pengaruh kecerdasan intelektual terhadap pemahaman akuntansi keuangan menengah. Hal ini ditunjukan dari dari nilai $t$ hitung sebesar 2.096 dengan signifikansi 0.043 yang lebih kecil dari 0.05 . Tabel diatas motivasi berpengaruh tidak signifikan terhadap pemahaman akuntansi keuangan menengah dengan nilai $t$ hitung sebesar 1.966 dan signifikansi 0.057 yang lebih besar dari 0.05 .

\section{Pengaruh Perilaku Belajar Terhadap Pemahaman Akuntansi Dasar Dengan Motivasi sebagai Variabel Moderating. \\ Tabel 13. Hasi uji F (ANOVA)}

\begin{tabular}{|l|l|l|l|l|l|}
\hline \hline $\begin{array}{c}\text { Sumb } \\
\mathbf{e r} \\
\text { varian }\end{array}$ & $\begin{array}{c}\text { Juml } \\
\text { ah } \\
\text { kuadr } \\
\text { at }\end{array}$ & $\begin{array}{c}\mathbf{D} \\
\mathbf{f}\end{array}$ & $\begin{array}{c}\text { Kuadr } \\
\text { at } \\
\text { tenga } \\
\mathbf{h}\end{array}$ & $\begin{array}{c}\mathbf{F} \\
\text { hitu } \\
\mathbf{n g}\end{array}$ & Sig. \\
\hline $\begin{array}{l}\text { Regre } \\
\text { si }\end{array}$ & 4.178 & 5 & 0.836 & $\begin{array}{l}1.82 \\
5\end{array}$ & $\begin{array}{l}.13 \\
2^{\mathrm{b}}\end{array}$ \\
\hline Sisa & $\begin{array}{l}16.93 \\
8\end{array}$ & 3 & 0.458 & & \\
\hline Total & $\begin{array}{l}21.11 \\
6\end{array}$ & 4 & & & \\
\hline
\end{tabular}

Sumber : Data Diolah (2019)

Berdasarkan tabel diatas dapat diketahui nilai $F$ hitung yang diperoleh dari pengolahan data adalah 1.825 dengan tingkat siginifikansi sebesar 0,132 atau lebih besar 0.05 maka Ho diterima dengan Ha ditolak, yang artinya model yang digunakan adalah untuk mengetahui berpengaruh tidak siginifikan kecerdasan intelektual $\left(X_{1}\right)$, perilaku belajar $\left(X_{2}\right)$, ketersediaan sarana pendidikan $\left(X_{3}\right)$ dan motivasi $\left(\mathrm{X}_{4}\right)$ terhadap pemahaman akuntansi keuangan menengah (Y).

Uji $t$ dapat digunakan untuk mengetahui signifikan atau tidaknya pengaruh secara parsial kecerdasan intelektual $\left(X_{1}\right)$, perilaku belajar $\left(X_{2}\right)$, ketersediaan sarana pendidikan $\left(X_{3}\right)$ dan motivasi $\left(X_{4}\right)$ terhadap pemahaman akuntansi keuangan menengah $(\mathrm{Y})$.

Tabel 14. Hasil uji t

\begin{tabular}{|c|c|c|c|c|}
\hline $\begin{array}{c}\text { Varia } \\
\text { bel }\end{array}$ & $\begin{array}{c}\text { t } \\
\text { hitu } \\
\text { ng }\end{array}$ & Sign. & $\begin{array}{c}\text { Kriteria } \\
\text { Penguji } \\
\text { an }\end{array}$ & $\begin{array}{c}\text { Kesimpu } \\
\text { lan }\end{array}$ \\
\hline $\begin{array}{l}\text { Kecer } \\
\text { dasan } \\
\text { Intelek } \\
\text { tual } \\
\left(X_{1}\right)\end{array}$ & $\begin{array}{l}- \\
1.78 \\
2\end{array}$ & 0.083 & \multirow{5}{*}{$\begin{array}{l}\text { Jika } \\
\text { nilai } \\
\text { probabil } \\
\text { itas (P } \\
\text { value)/s } \\
\text { ignifika } \\
\mathrm{n}>0.05 \\
\text { maka } \\
\text { Ho } \\
\text { diterima } \\
\text { dan Ha } \\
\text { ditolak } \\
\text { Jika } \\
\text { nilai } \\
\text { probabil } \\
\text { itas ( } \mathrm{P} \\
\text { value }) / \mathrm{s} \\
\text { ignifika } \\
\mathrm{n}<0.05 \\
\text { maka } \\
\text { Ho } \\
\text { ditolak } \\
\text { dan Ha } \\
\text { diterima }\end{array}$} & $\begin{array}{l}\text { Ho } \\
\text { diterima } \\
\text { dan Ha } \\
\text { ditolak }\end{array}$ \\
\hline $\begin{array}{l}\text { Perila } \\
\text { ku } \\
\text { Belaja } \\
\mathrm{r}\left(\mathrm{X}_{2}\right) \\
\end{array}$ & $\begin{array}{l}0.2 \\
84\end{array}$ & $\begin{array}{l}0.77 \\
8\end{array}$ & & $\begin{array}{l}\text { Ho } \\
\text { diterima } \\
\text { dan } \mathrm{Ha} \\
\text { ditolak }\end{array}$ \\
\hline $\begin{array}{l}\text { Keters } \\
\text { ediaan } \\
\text { Saran } \\
\text { a } \\
\text { Pendi } \\
\text { dikan } \\
\left(\mathrm{X}_{3}\right) \\
\end{array}$ & $\begin{array}{l}0.0 \\
34\end{array}$ & $\begin{array}{l}0.97 \\
3\end{array}$ & & $\begin{array}{l}\text { Ho } \\
\text { diterima } \\
\text { dan } \mathrm{Ha} \\
\text { ditolak }\end{array}$ \\
\hline $\begin{array}{l}\text { Motiva } \\
\text { si }\left(X_{4}\right)\end{array}$ & $\begin{array}{l}2.2 \\
72\end{array}$ & $\begin{array}{l}0.02 \\
9\end{array}$ & & $\begin{array}{l}\text { Ho } \\
\text { ditolak } \\
\text { dan } \mathrm{Ha} \\
\text { diterima }\end{array}$ \\
\hline $\begin{array}{l}\text { Intera } \\
\text { ksi } \\
\text { antara } \\
\text { variab } \\
\text { el } \\
\text { Perila } \\
\text { ku } \\
\text { Belaja } \\
\text { r dan } \\
\text { Motiva } \\
\text { si } \\
\left(\mathrm{X}_{2} \mathrm{X}_{4}\right. \\
) \\
\end{array}$ & $\begin{array}{l}2.1 \\
68\end{array}$ & $\begin{array}{l}0.03 \\
7\end{array}$ & & $\begin{array}{l}\text { Ho } \\
\text { ditolak } \\
\text { dan } \mathrm{Ha} \\
\text { diterima }\end{array}$ \\
\hline
\end{tabular}

Sumber : Data Diolah (2019)

Hasil uji t menunjukkan bahwa variabel kecerdasan intelektual $\left(\mathrm{X}_{1}\right)$, berpengaruh tidak signifikan terhadap pemahaman mahasiswa prodi akuntansi semester 5 Universitas Muhammadiyah Surabaya mengenai akuntansi keuangan menengah. Hal ini ditunjukkan dari nilai $t$ hitung sebesar -1.782 dengan signifikansi 0.083 yang lebih besar dari 0.05 . Hasil uji t berikutnya menunjukkan bahwa terdapat pengaruh tidak signifikan perilaku belajar $\left(\mathrm{X}_{2}\right)$ terhadap pemahaman akuntansi 
keuangan menengah. Hal tersebut ditunjukkan dari nilai $t$ hitung sebesar 0.284 dengan signifikansi 0.778 yang lebih besar dari 0.05 .

Hasil uji t juga menunjukkan bahwa variabel ketersediaan sarana pendidikan $\left(\mathrm{X}_{3}\right)$, berpengaruh tidak signifikan terhadap pemahaman mahasiswa prodi akuntansi semester 5 Universitas Muhammadiyah Surabaya mengenai akuntansi keuangan menengah. Hal ini ditunjukkan dari nilai $t$ hitung sebesar 0.034 dengan signifikansi 0.973 yang lebih besar dari 0.05. Untuk hasil uji t menunjukan pula bahwa motivasi memoderasi pengaruh perilaku belajar terhadap pemahaman akuntansi keuangan menengah. Hal ini ditunjukan dari dari nilai $\mathrm{t}$ hitung sebesar 2.168 dengan signifikansi 0.037 yang lebih kecil dari 0.05 . Tetapi dtunjukkan pada tabel diatas bahwa motivasi mempunyai pengaruh terhadap pemahaman akuntansi dasar jika sebagai variabel bebas bukan sebagai variabel moderating dengan nilai $t$ hitung sebesar 2.272 dan signifikansi 0.029 yang lebih kecil dari 0.05 .

3. Pengaruh Ketersediaan Sarana Pendidikan Terhadap Pemahaman Akuntansi Keuangan Menengah Dengan Motivasi sebagai Variabel Moderating.

Tabel 15. Hasi uji F (ANOVA)

\begin{tabular}{|c|c|c|c|c|c|}
\hline $\begin{array}{c}\text { Sum } \\
\text { ber } \\
\text { varia } \\
\mathbf{n}\end{array}$ & $\begin{array}{c}\text { Jum } \\
\text { lah } \\
\text { kua } \\
\text { drat }\end{array}$ & Df & $\begin{array}{c}\text { Kuadr } \\
\text { at } \\
\text { tenga } \\
\mathbf{h}\end{array}$ & $\begin{array}{c}\mathbf{F} \\
\text { hitung }\end{array}$ & Sig. \\
\hline $\begin{array}{l}\text { Regr } \\
\text { esi }\end{array}$ & $\begin{array}{r}3.3 \\
95\end{array}$ & 5 & 0.679 & 1.418 & $\begin{array}{r}.24 \\
1^{\mathrm{b}}\end{array}$ \\
\hline Sisa & $\begin{array}{r}17 . \\
72\end{array}$ & 3 & 0.479 & & \\
& 1 & 7 & & & \\
\hline Total & $\begin{array}{r}21 . \\
11\end{array}$ & 4 & & & \\
& 6 & 2 & & & \\
\hline
\end{tabular}

Sumber : Data Diolah (2019)

Berdasarkan tabel diatas dapat diketahui nilai $F$ hitung yang diperoleh dari pengolahan data adalah 1.418 dengan tingkat siginifikansi sebesar 0,241 atau lebih kecil 0.05 maka Ho ditolak dengan Ha diterima, yang artinya model yang digunakan adalah signifikan atau cocok untuk mengetahui pengaruh kecerdasan intelektual $\left(X_{1}\right)$, perilaku belajar $\left(X_{2}\right)$, ketersediaan sarana pendidikan $\left(X_{3}\right)$ dan motivasi $\left(\mathrm{X}_{4}\right)$ terhadap pemahaman akuntansi keuangan menengah $(\mathrm{Y})$. Tabel 16. Hasil uji t

\begin{tabular}{|c|c|c|c|c|}
\hline Variabel & t hit & Sign. & $\begin{array}{c}\text { Kriteria } \\
\text { Penguji } \\
\text { an }\end{array}$ & $\begin{array}{c}\text { Kesi } \\
\text { mpul } \\
\text { an }\end{array}$ \\
\hline $\begin{array}{l}\text { Kecerda } \\
\text { san } \\
\text { Intelektu } \\
\text { al }\left(X_{1}\right)\end{array}$ & -1.941 & 0.060 & $\begin{array}{l}\text { Jika nilai } \\
\text { probabili } \\
\text { tas }(P \\
\text { value)/si } \\
\text { gnifikan } \\
>\quad 0.05 \\
\text { maka Ho }\end{array}$ & $\begin{array}{l}\text { Ho } \\
\text { diteri } \\
\text { ma } \\
\text { dan } \\
\text { Ha } \\
\text { ditola } \\
\text { k }\end{array}$ \\
\hline $\begin{array}{l}\text { Perilaku } \\
\text { Belajar } \\
\left(X_{2}\right)\end{array}$ & $\begin{array}{l}1.01 \\
3\end{array}$ & $\begin{array}{l}0.31 \\
8\end{array}$ & $\begin{array}{l}\text { diterima } \\
\text { dan Ha } \\
\text { ditolak } \\
\text { Jika nilai } \\
\text { probabili } \\
\text { tas (P }(\mathrm{P} \\
\text { value)/si }\end{array}$ & $\begin{array}{l}\text { Ho } \\
\text { diteri } \\
\text { ma } \\
\text { dan } \\
\text { Ha } \\
\text { ditola } \\
\text { k }\end{array}$ \\
\hline $\begin{array}{l}\text { Ketersed } \\
\text { iaan } \\
\text { Sarana } \\
\text { Pendidik } \\
\text { an }\left(X_{3}\right)\end{array}$ & $\begin{array}{l}0.26 \\
4\end{array}$ & $\begin{array}{l}0.79 \\
4\end{array}$ & $\begin{array}{l}\text { gnifikan } \\
<\quad 0.05 \\
\text { maka Ho } \\
\text { ditolak } \\
\text { dan Ha } \\
\text { diterima }\end{array}$ & $\begin{array}{l}\text { Ho } \\
\text { diteri } \\
\text { ma } \\
\text { dan } \\
\text { Ha } \\
\text { ditola } \\
\text { k }\end{array}$ \\
\hline $\begin{array}{l}\text { Motivasi } \\
\left(\mathrm{X}_{4}\right)\end{array}$ & $\begin{array}{l}1.99 \\
4\end{array}$ & $\begin{array}{l}0.05 \\
4\end{array}$ & & $\begin{array}{l}\text { Ho } \\
\text { diteri } \\
\text { ma } \\
\text { dan } \\
\text { Ha } \\
\text { ditola } \\
\text { k }\end{array}$ \\
\hline $\begin{array}{l}\text { Interaksi } \\
\text { antara } \\
\text { variabel } \\
\text { Ketersed } \\
\text { iaan } \\
\text { Sarana } \\
\text { Pendidik } \\
\text { an dan } \\
\text { Motivasi } \\
\left(X_{2} X_{4}\right)\end{array}$ & $\begin{array}{l}1.69 \\
0\end{array}$ & $\begin{array}{l}0.09 \\
9\end{array}$ & & $\begin{array}{l}\text { Ho } \\
\text { diteri } \\
\text { ma } \\
\text { dan } \\
\text { Ha } \\
\text { ditola } \\
\text { k }\end{array}$ \\
\hline
\end{tabular}

Sumber : Data Diolah (2019)

Hasil uji t menunjukkan bahwa variabel kecerdasan intelektual $\left(\mathrm{X}_{1}\right)$, berpengaruh tidak signifikan terhadap pemahaman mahasiswa prodi akuntansi semester 5 Universitas Muhammadiyah Surabaya mengenai akuntansi keuangan menengah. Hal ini ditunjukkan dari nilai t hitung sebesar -1.941 dengan signifikansi 
0.060 yang lebih besar dari 0.05 . Hasil uji $\mathrm{t}$ berikutnya menunjukkan bahwa terdapat pengaruh tidak signifikan perilaku belajar $\left(\mathrm{X}_{2}\right)$ terhadap pemahaman akuntansi keuangan menengah. Hal tersebut ditunjukkan dari nilai t hitung sebesar 1.013 dengan signifikansi 0.318 yang lebih besar dari 0.05 .

Hasil uji $t$ juga menunjukkan bahwa variabel ketersediaan sarana pendidikan $\left(X_{3}\right)$, berpengaruh tidak signifikan terhadap pemahaman mahasiswa prodi akuntansi semester 5 Universitas Muhammadiyah Surabaya mengenai akuntansi keuangan menengah. Hal ini ditunjukkan dari nilai $t$ hitung sebesar 0.264 dengan signifikansi 0.794 yang lebih besar dari 0.05. Untuk hasil uji t menunjukan pula bahwa motivasi tidak memoderasi pengaruh ketersediaan sarana pendidikan terhadap pemahaman akuntansi keuangan menengah. Hal ini ditunjukan dari dari nilai $t$ hitung sebesar 1.690 dengan signifikansi 0.099 yang lebih kecil dari 0.05. Tabel diatas motivasi berpengaruh tidak signifikan terhadap pemahaman akuntansi keuangan menengah dengan nilai $t$ hitung sebesar 1.994 dan signifikansi 0.054 yang lebih besar dari 0.05

\section{Pengaruh Kecerdasan Intelektual Terhadap Pemahaman Akuntansi Keuangan Menengah Dengan Motivasi sebagai Variabel Moderating.} berpengaruh tidak

signifikan terhadap pemahaman akuntansi keuangan menengah dengan nilai signifikan diatas 0.05 yaitu sebesar 0.176 . Kecerdasan intelektual adalah kemampuan intelektual, analisa, logika dan rasio yang dimiliki oleh seorang mahasiswa. Ermawati dan Kuncoro, 2017 dalam penelitian menjelaskan bahwa daya ingat yang tinggi akan menghasilkan nilai akhir belajar yang bagus, jika kecerdasan intelektual tinggai maka daya ingat tinggi. Namun hasil penelitian ini menunjukkan bahwa mahasiswa kecerdasan intelektual tinggi masih belum bisa memahami akuntansi keuangan menengah. Hal ini disebabkan karena mahasiswa prodi akuntansi semester 5 belum memahami secara detail metode perlakuan akuntansi dari rekening riil yang meliputi pengakuan, pengukuran, penyajian dan pengungkapan baik secara teori maupun praktek. Dan tentu saja kurangnya mahasiswa akan pratikum akuntansi keuangan memengah sehingga masih belum terbiasa akan berbagai jenis soal kasus. Hasil penelitian ini sejalan dengan dengan penelitian yang dilakukan oleh (Ernawati, 2017), tetapi penelitian ini tidak mendukung penelitian Yorika dkk (2013) dan (Pasek, 2015). Hasil uji statistik berikutnya menunjukan bahwa motivasi memoderasi pengaruh kecerdasan intelektual terhadap pemahaman akuntansi keuangan menengah yang menunjukkan nilai signifikan dibawah 0.05 yaitu sebesar 0.043. Hal tersebut menunjukkan bahwa motivasi dapat memperkuat pengaruh kecerdasan intelektual terhadap pemahaman akuntansi keuangan menengah. Jika mahasiswa mempunyai motivasi yang tinggi dalam memahami, mengerti konsep akuntansi keuangan menengah diimbangi dengan daya ingat tinggi maka akan mudah bagi mahasiswa tersebut dalam mengerjakan soal studi kasus akuntansi keuangan menengah. Semakin tinggi motivasi maka semakin tinggi kecerdasan intelektual yang tinggi dikarenakan mahasiswa akan selalu berusaha untuk bisa memahami, mengerti konsep akuntansi keuangan menengah.

2. Pengaruh Perilaku Belajar Terhadap Pemahaman Akuntansi Dasar Dengan Motivasi sebagai Variabel Moderating.

Hasil uji regresi menunjukkan variabel perilaku belajar berpengaruh tidak signifikan terhadap pemahaman akuntansi keuangan menengah dengan nilai signifikan diatas 0.05 yaitu sebesar 0.778. Perilaku belajar dapat diartikan sebagai kebiasaan belajar, dan merupakan dimensi belajar yang dilakukan oleh individu secara berulang-ulang sehingga menjadi otomatis (Filia, 2010). Namun hasil penelitian ini menunjukkan bahwa perilaku belajar mahasiswa masih belum bisa menunjukkan pemahaman akuntansi keuangan menengah. Hal ini 
disebabkan karena mahasiswa prodi akuntansi semester 5 belum bisa memanfaatkan waktu dengan baik untuk melakukan berbagai cara agar bisa memahami lebih detail akuntansi keuangan menengah. Misalnya kurangnya kebiasaan mahasiswa membaca buku diperpustakaan, kurang tanggapnya mahasiswa untuk membeli buku akuntansi guna menunjang pemahaman akuntansi keuangan menengah. Hasil penelitian ini sejalan dengan dengan penelitian yang dilakukan oleh (Widyawati \& dkk, 2014), tetapi penelitian ini tidak mendukung penelitian (Juliastantri, 2014) dan Komalasari (2013). Hasil uji statistik berikutnya menunjukan bahwa motivasi memoderasi pengaruh perilaku belajar terhadap pemahaman akuntansi keuangan menengah menunjukkan nilai signifikan dibawah 0.05 yaitu sebesar 0.037 . Hal tersebut menunjukkan bahwa motivasi dapat memperkuat pengaruh perilaku belajar terhadap pemahaman akuntansi keuangan menengah. Jika mahasiswa mempunyai motivasi yang tinggi dalam memahami, mengerti konsep akuntansi keuangan menengah diimbangi dengan perilaku belajar yang teratur maka akan mudah bagi mahasiswa tersebut dalam memahami, mengerti akuntansi keuangan menengah baik secara teori maupun praktek. Dalam pengujian analisis dan uji hipotesis kedua motivasi mempunyai pengaruh terhadap pemahaman akuntansi keuangan menengah sebagai variabel bebas bukan variabel moderating sehingga motivasi dalam penelitian ini juga memperkuat perilaku belajar dalam mempengaruhi pemahaman akuntansi keuangan menengah.

\section{Pengaruh Ketersediaan Sarana Pendidikan Terhadap Pemahaman Akuntansi Dasar Dengan Motivasi sebagai Variabel Moderating.}

Hasil uji regresi menunjukkan variabel ketersediaan sarana pendidikan berpengaruh tidak signifikan terhadap pemahaman akuntansi keuangan menengah dengan nilai signifikan diatas 0.05 yaitu sebesar 0.794. Sarana pendidikan yang digunakan adalah fasilitas berupa perangkat alat, bahan dan perabot yang secara langsung digunakan dalam proses pendidikan. Bentuk sarana pendidikan dimanfaatkan untuk memperoleh, menggali informasi mengenai pemahaman akuntansi keuangan menengah seperti jurnal, referensi buku, internet dan lainnya. Namun hasil penelitian ini menunjukkan bahwa ketersediaan sarana pendidikan masih belum bisa menunjang pemahaman akuntansi keuangan menengah. Hal ini disebabkan karena mahasiswa prodi akuntansi semester 5 merasa masih kurangnya sarana prasarana yang menunjang matakuliah kompetensi yaitu akuntansi. Misalnya masih belum adanya ruang pratikum akuntansi, konectisitas wifi masih belum lancar, belum adanya ruang perpustakaan difakultas ekonomi dan bisnis, dan kurang updatenya buku referensi akuntansi. Hasil penelitian ini sejalan dengan dengan penelitian yang dilakukan oleh (Sitawati, 2017), tetapi penelitian ini tidak mendukung penelitian (Widaningrum \& dkk, 2010). Hasil uji statistik berikutnya menunjukan bahwa motivasi tidak memoderasi pengaruh ketersediaan sarana pendidikan terhadap pemahaman akuntansi keuangan menengah yang menunjukkan nilai signifikan diatas 0.05 yaitu sebesar 0.099 . Hal tersebut menunjukkan bahwa ketersediaan sarana pendidikan masih dalam kondisi kurang lengkap dalam menunjang pemahaman akuntansi keuangan menengah secara detail.

\section{KESIMPULAN}

Berdasarkan hasil penelitian
disimpulkan bahwa kecerdasan
intelektual, perilaku belajar dan
ketersediaan sarana pendidikan
berpengaruh tidak signifikan terhadap
pemahaman akuntansi keuangan
menengah. Hal ini bisa saja disebabkan
karena banyak faktor lainnya tidak
teramati dalam penelitian ini misalnya
kebiasaan mahasiswa yang masih belum
terbiasa untuk mengunjungi
perpusatakaan dalam hal membaca
maupun meminjam buku, memanfaatkan
fasilitas wifi kampus, sehingga tidak
adanya dorongan/kebiasaaan atau
motivasi untuk lebih mengetahui jika ada


materi atau soal yang belum bisa dimengerti. Motivasi hanya memoderasi pengaruh kecerdasan intelektual dan perilaku belajar terhadap pemahaman akuntansi keuangan menengah.

Diharapkan mahasiswa untuk lebih memahami, mempelajari konsep akuntansi keuangan menengah dari sumber manapun, antara lain belajar dari buku-buku text book, belajar dari browsing internet, mengunjungi perpustakaan, kursus akuntansi atau bertanya secara pribadi pada dosen pengampu matakuliah akuntansi apabila ada materi atau soal yang belum bisa dimengerti, dan lain sebagainya. Keterbatasan dalam penelitian ini sampel yang diambil hanya pada satu perguruan tinggi.

\section{IMPLIKASI KETERBATASAN}

Peneliti menyadari bahwa dalam penelitian ini terdapat beberapa keterbatasan yang mungkin dapat mempengaruhi hasil penelitian. Keterbatasan-keterbatasan tersebut antara lain :

1. Kemungkinan adanya perbedaan persepsi diantara masing-masing responden di dalam memahami konteks pernyataan yang disajikan dalam kuisioner.

2. Jawaban responden yang disampaikan secara tertulis melalui kuisioner belum tentu mencerminkan keadaan yang sebenarnya yang akan berbeda apabila data diperoleh melalui wawancara langsung.

3. Kendala yang bersifat situasional, yaitu berupa situasi yang dirasakan responden pada saat pengisian kuisioner tersebut akan dapat mempengaruhi cara menjawab.

\section{REFERENCES}

\section{Agustian Ary Ginanjar Emotional} Spiritual Quotient The ESQ Way 165 [Buku]. - Jakarta: Arga Publishing, 2007.
Anonim

(http://id.wikipedia.org/wiki/kecerdasan _intelektual). [Online]. (http://id.wikipedia.org/wiki/kecerdasan _intelektual). .

Anonim http://www.AnneAhira.com [Online]. 2010. http://www.AnneAhira.com, 2010.

Anonim ian43.wordpress.com [Online]. $17 \quad 12 \quad$ 2015. ian43.wordpress.com/2015/12/17/peng ertian-pemahaman.

Anonim pengertian-pengertianinfo.blogspot.co.id [Online]. - 12 2015. pengertian-pengertianinfo.blogspot.co.id/2015/12/pengeetian -pemahaman-menurut-ahli.html.

Anonim www.ainamulyana.blogspot.co.id [Online]. - $04 \quad 2015$. www.ainamulyana.blogspot.co.id/2015/ 04/pengertian-ciri-dan-jeniskecerdasan.html.

Anonim www.asikbelajar.com [Online]. 05 2013. www.asikbelajar.com/2013/05/pemaha man-belajar.html.

Anonim www.dewasastra.wordpress.com [Online]. - $21 \quad 03 \quad$ 2012. www.dewasastra.wordpress.com/2012 /03/21/konsep-dasar-kecerdasan.

Anonim www.duniapelajar.com [Online]. 02092011 . www.duniapelajar.com/2011/09/02/defi nisi-pemahaman-menurut-para-ahli.

Anonim www.gelombangotak.com [Online]. www.gelombangotak.com/pengertiankecerdasan-spiritual\%20(SQ).htm.

Anonim www.jelajahinternet.com [Online]. - $18 \quad 10 \quad$ 2015. - 
www.jelajahinternet.com/2015/10/18/p engertian-kecerdasan-intelektual.html.

Anonim www.kajianpustaka.com

[Online]. 9

2013. www.kajianpustaka.com/2013/09/peng ertian-dan-jenis-jenis-kecerdasan.html.

Anonim www.pengertianahli.com

[Online]. 12 2013. www.pengertianahli.com/2013/12/peng ertian-dan-jenis-jenis-kecerdasan.html.

Danah Zohar, Marshall dan lan Kecerdasan Spiritual, Terjemahan Rahmani Astuti, Ahmad Nadjib, Ahmad Baiquni [Buku]. - Bandung: Mizan, 2007.

Ernawati Kuncoro Faktor-faktor yang Mempengaruhi Tingkat Pemahaman IFRS (Internasional Financial Reporting Standar) $\quad$ Jurnal] $=$ ISSN No.2085$5656 / /$ Jurnal STIE Semarang. Semarang : [s.n.], Februari 2017. - Vol. Vol.9, No.01.

Filia Rachmi Pengaruh Kecerdasan Emosional, Kecerdasan Spiritual dan Perilaku Belajar Terhadap Pemahaman Akuntansi// Skripsi Mahasiswa S1 Fakultas Ekonomi Universitas Diponegoro Semarang. - Semarang: [s.n.], 2010.

Ghozali Imam Aplikasi Analisis Multivariate dengan Program SPSS [Bagian Buku]. - Semarang: Undip, 2013.

Goleman Daniel Working with Emotional Intelligence [Buku]. - Jakarta : Gramedia Pustaka Utama, 2000.

Handoko Hani Manajemen [Buku]/ penyunt. 2. - Yogyakarta : BPFE Yogyakarta, 2011.
Husein Umar Metode Penelitian Untuk Skripsi dan Tesis Bisnis [Buku]. Jakarta : Raja Grafindo Persada, 2004.

Juliastantri Dwi Maya Pengaruh Kecerdasan Emosional,Kecerdasan Spiritual dan Perilaku Belajar Terhadap Tingkat Pemahaman Akuntansi (Studi Empiris Mahasiswa Fakultas Ekonomi Jurusan Akuntansi Angkatan Tahun2010 Universitas Jember) [Artikel] // Artikel Ilmiah S1 Fakultas Ekonomi Universitas Jember. Jember : [s.n.], 2014.

Martani Dwi Akuntansi Keuangan Berbasis PSAK [Buku]. - Jakarta: Salemba Empat, 2016. - 2 : Vol. Buku 1.

Nurdiansyah Junifar Pengaruh Kecerdasan Emosional, Kecerdasan Spiritual dan Perilaku Belajar Terhadap Tingkat Pemahaman Akuntansi [Jurnal] // Jurnal IImu dan Riset Akuntansi. - 2015. - Vol. Vol.4, No.10.

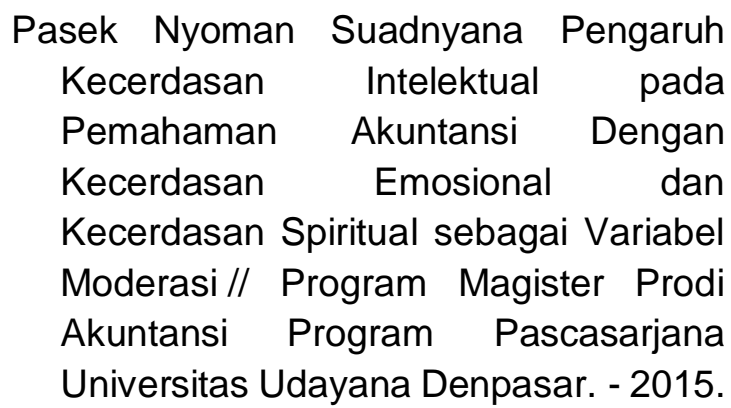

Sahara As Masyitah Pengaruh Perilaku Belajar, Kecerdasan Emosional, Kecerdasan Intelektual, Kecerdasan Spiritual dan Kecerdasan Sosial Terhadap Pemahaman Akuntansi [Artikel] // Artikel IImiah Mahasiswa S1 Fakultas Ekonomi Universitas Maritim Raja Ali Haji. - 2014.

Sitawati Pitoyo Pengaruh Sarana Prasana Pendidikan dan Kecerdasan Emosional (EQ) Terhadap Tingkat Pemahaman Akuntansi Mahasiswa Dengan Minat Belajar sebagai Variabel Intervening 
(Studi Kasus Mahasiswa AMIK JTC Semarang Angkatan 2012-2014) [Jurnal] // INFOKAM. - Maret 2017. No.I,Th.XIII.

Sugiyono Metode Penelitian Pendidikan (Pendekatan Kuantitatif, Kualitatif dan R\&D) [Buku]. - Bandung : CV.Alfabeta, 2012.

Sumarsono Metode Penelitian Akuntansi (Beberapa contoh Interpretasi Hasil Pengolahan Data) [Buku]. - [s.I.] : Unesa Unversity Press, 2007.

Widaningrum dan dkk Pengaruh Ketersediaan Sarana Pendidikan dan Kecerdasan Emosional Terhadap Tingkat Pemahaman IFRS dengan Minat sebagai variabel Moderating di Fakultas Ekonomi UNSOED // Simposium Nasional Akuntansi XIII. Purwokerto : [s.n.], 2010.

Widyawati dan dkk Pengaruh Kecerdasan Emosional,Perilaku Belajar dan Budaya Terhadap Tingkat Pemahaman Akuntansi Dengan Kepercayaan Diri Sebagai Variabel Moderating (Studi Empiris pada Mahasiswa di Perguruan Tinggi Swasta Kota Madiun) [Jurnal] = ISSN Online. 2338-6576 // Jurnal Riset Manajemen dan Akuntansi. - Madiun : [s.n.], Februari 2014. - Vol. Vol.2, No.01.

Zaikah Farah Pengaruh Kecerdasan Emosional, Kecerdasan Intelektual dan Kecerdasan Spiritual Terhadap Pemahaman Akuntansi (Studi Empiris Mahasiswa Jurusan Akuntansi Angkatan 2009 di Universitas Jember) // Skripsi Mahasiswa Jurusan Akuntansi S1 Fakultas Ekonomi Universitas Jember. - Jember: [s.n.], 2013 